\title{
Purification and Characterization of Lacticin NK34 Produced by Lactococcus lactis NK34 against Bovine Mastitis
}

Na-Kyoung Lee, Yeo-Lang Park, Hyoun Wook Kim, Yong-Ho Park', Seong-Lyul Rhim², Jong-Man Kim³ Jae-Myung Kim³ ${ }^{3}$ Hyang-Mi Nam ${ }^{3}$, Suk-Chan Jung ${ }^{3}$, and Hyun-Dong Paik*

Division of Animal Life Science, Konkuk University, Seoul 143-701, Korea

'College of Veterinary Medicine, Seoul University, Seoul 157-142, Korea

${ }^{2}$ Department of Biomedical Science, Hallym University, Chuncheon, Gangwon 200-702, Korea

${ }^{3}$ National Veterinary Research \& Quarantine Service, Anyang 430-824, Korea

\section{Lactococcus lactis NK34에 의해 생산된 소 유방염 원인균에 효과가 있는 lacticin NK34의 정제 및 특성}

\author{
이나경 - 박여랑 - 김현욱 - 박용호 ${ }^{1}$ - 임성렬 ${ }^{2}$ - 김종만 ${ }^{3}$ - 김재명 ${ }^{3}$ - 남향미 ${ }^{3}$ - 정석찬 ${ }^{3}$ - 백현동* \\ 건국대학교 동물생명과학부, ${ }^{1}$ 서울대학교 수의학과, ${ }^{2}$ 한림대학교 바이오메디칼학과, ${ }^{3}$ 국립수의과학검역원
}

\begin{abstract}
Lactococcus lactis NK34, isolated from jeotgal (Korean traditional fermented fish), produces bacteriocin against bovine mastitis pathogens such as Staphylococcus aureus 7, S. aureus 8, Staphylococcus chromogenes 10, S. chromogenes 19, Staphylococcus hominis 9, Streptococcus uberis E290, Enterococcus faecium E372, Streptococcus agalactiae ATCC 13813, Pseudonocardia autotrophia KCTC 9455, and Staphylococcus simulans 78. Lacticin NK34 was inactivated by protease XIV but not by protease IX, protease XIII, proteinase K, á-chymotrypsin, trypsin, and pepsin. Also, lacticin NK34 was stable over a pH range of 2 to 9 for $4 \mathrm{hr}$ and withstood exposure to temperatures of $30-100^{\circ} \mathrm{C}$ for 30 min. Lacticin NK34 showed bactericidal effects against $S$. simulans 78 . This bacteriocin was purified using ammonium sulfate precipitation, ion exchange chromatography, ultrafiltration, and hydrophobic chromatography. Tricin-SDS-PAGE of purified bacteriocin gave the same molecular weight $(3.5 \mathrm{kDa})$ as nisin. The gene encoding this bacteriocin was amplified by PCR using nisin gene-specific primers. It showed similar sequences to this nisin Z gene. These results indicate that lacticin NK34 is a nisinlike bacteriocin, and could be used as an antimicrobial alternative for livestock.
\end{abstract}

Key words : Lactococcus lactis NK34, lacticin NK34, bovine mastitis, purification, characterization, nisin

\section{Introduction}

Bacteriocins are proteinaceous bacterial products which have bactericidal activity. They are produced by various lactic acid bacteria (LAB) including lactococci, lactobacilli, leuconostoc, and pediococci (Klaenhammer, 1988; Nes et al., 2007). Many bacteriocins produced by LAB inhibited not only species closely related to the producer strain, but also the growth of food-borne pathogens such as Listeria

*Corresponding author : Hyun-Dong Paik, Division of Animal Life Science, Konkuk University, Seoul 143-701, Korea. Tel: 82-2-2049-6011, Fax: 82-2-455-3082, E-mail: hdpaik@konkuk. ac.kr monocytogenes, Clostridium botulinum, etc. Bacteriocin was applied various foods such as dairy products (Weinbrenner et al., 1997; Oh et al., 2006), sous vide product (Kim et al., 2008), meat (Lee et al., 2008), canned foods, etc.

The bacteriocins of $\mathrm{LAB}$ are classified into four classes (Klaenhammer, 1998). Class I bacteriocins or lantibiotics, are small $(<5 \mathrm{kDa})$ membrane active peptides, which contain post-translationally modified amino acid residues like lanthionine. Representative class I bacteriocin is known as nisin. Class II bacteriocins are small, heat-stable, nonlanthionine-containing peptides, including class IIa, Listeria active peptides; class $\Pi \mathrm{lb}$, small cationic peptide; and class IIc, sec-dependent secreted bacteriocin.

Bovine mastitis is a disease caused by infection of cow 
udders and is one of the most significant causes of economic losses to the dairy industry due to rejected milk, degraded expenses, and increased labor costs (Green et al., 2002). Staphylococcus aureus and Streptococcus spp. are main bacterial agents in this disease (Bradley, 2002). Treatment of bovine mastitis have generally used with antibiotics, however, antibiotics may leave harmful residues in raw milk. Bacteriocin may be an alternative to conventional antibiotics.

Nisin has been the most extensively studied bacteriocin. Nisin is permitted as a food additive in at least 46 countries, on dairy products and canned foods (Delves-Broughton, 1990). Also, nisin is inhibitory to many mastitis strains. Lacticin 3147 was reported as a bacteriocin having inhibitory activity against mastitis pathogens using teat seals (Ryan $e t$ al., 1998; Twomey et al., 2000). The bacteriocin produced by Lactobacillus bulgaricus showed antibacterial activity against antibiotic resistant strain, S. aureus ATCC 6538 (Kim et al., 2004). Also, bacteriocin produced by $S$. aureus isolated from cows having bovine mastitis was studied (Nascimento et al., 2002; Coelho et al., 2007).

We describe here the characterization and purification of lacticin NK34 isolated from jeotgal having antimicrobial activity against bovine mastitis-related microorganisms.

\section{Materials and Methods}

\section{Bacterial strains and culture media}

Lactococcus lactis NK34 was isolated from jeotgal, cultured in lactobacilli MRS medium (Difco Laboratories, Detroit, MI, USA) at $35^{\circ} \mathrm{C}$. Staphylococcus simulans 78 was used as indicator bacterium for bacteriocin activity. S. simulans 78 was cultured in tryptic soy broth (TSB, Difco) at $35^{\circ} \mathrm{C}$. Other strains listed in Table 2 were obtained from National Veterinary Research \& Quarantine Service and Seoul National University. These strains were cultured in TSB agar at $35^{\circ} \mathrm{C}$ and were stored at $-70^{\circ} \mathrm{C}$ in medium with $20 \%$ (v/v) glycerol.

\section{Determination of bacteriocin activity}

Lacticin NK34 activity was determined by spot-on-lawn method (Lee and Paik, 2001). Soft agar seeded (1\%, v/v) with the indicator organisms was overlayed on the plate, and was allowed to solidify. Concentrated lacticin NK34 solution was diluted serially using two-fold dilution, and $5 \mu \mathrm{L}$ of each dilution was spotted on the plate. The plates were incubated at $35^{\circ} \mathrm{C}$ overnight. The bacteriocin activity was determined in arbitrary unit (AU) as follows: Bacteriocin activity $(\mathrm{AU} / \mathrm{mL})=2^{\mathrm{N}} \times 200$, where $\mathrm{N}=$ dilution number with the smallest zone of inhibition.

\section{Production and ammonium sulfate precipitation of the bacteriocin}

L. lactis NK34 was grown to stationary phase in $2 \mathrm{~L}$ flask containing $1.5 \mathrm{~L}$ of lactobacilli MRS medium at $35^{\circ} \mathrm{C}$. The cells were removed by centrifugation at $10,000 \times \mathrm{g}$ for $20 \mathrm{~min}$ at $4^{\circ} \mathrm{C}$. The culture supernatant was then precipitated with $60 \%$ ammonium sulfate. The precipitate was collected by centrifugation at $10,000 \times \mathrm{g}$ for $30 \mathrm{~min}$ at $4^{\circ} \mathrm{C}$, resuspended in a $100 \mathrm{mM}$ phosphate buffer ( $\mathrm{pH} 7.0)$, and dialyzed against 2 $\mathrm{L}$ of $10 \mathrm{mM}$ phosphate buffer ( $\mathrm{pH} 7.0$ ) for 12-18 hr in Spectra-Por no. 3 dialysis tubing (molecular weight cutoff, 3,500; Spectrum Medical Industries, Gardena, CA, USA). The dialyzed samples were stored at $-70^{\circ} \mathrm{C}$.

\section{Antimicrobial spectrum of lacticin NK34}

The antimicrobial spectrum was determined by the well diffusion assay. The supernatant $(100 \mu \mathrm{L})$ was placed in wells on TSB agar plate. The plate was turn upside down. Soft agar seeded $(1 \%, v / v)$ with the indicator organisms was the overlaid on the plate. The plates were incubated at $35^{\circ} \mathrm{C}$ overnight.

\section{Sensitivity of enzyme, $\mathrm{pH}$, and heat}

The sensitivity to protease IX, protease XIII, protease $\mathrm{XIV}$, proteinase $\mathrm{K}, \alpha$-chymotrypsin, trypsin, and pepsin was tested at a final concentration of $1 \mathrm{mg} / \mathrm{mL}$ for $1 \mathrm{hr}$. Effect of $\mathrm{pH}$ was tested a range of $\mathrm{pH} 3-9$ at $4^{\circ} \mathrm{C}$ for $4 \mathrm{hr}$. To test for heat sensitivity, lacticin NK34 was heated to $100^{\circ} \mathrm{C}$ for 30 $\min$.

\section{Mode of inhibition of lacticin NK34}

$0,2,560$ and $5,120 \mathrm{AU} / \mathrm{mL}$ of partially purified lacticin NK34 were used to determine the mode of inhibition. One milliliter of growing culture of $S$. simulans 78 in $9 \mathrm{~mL}$ of 0.1 M potassium phosphate buffer $(\mathrm{pH} 7.0)$ containing lacticin NK34 were incubated at $35^{\circ} \mathrm{C}$. Samples were collected on interval of $1 \mathrm{hr}$. Viable cells were counted by general plate counting on TSB agar.

\section{Purification of lacticin NK34}

Lacticin NK34 was purified by means of chromatography and ultrafiltration. Anion exchange chromatography was performed with DEAE-cellulose (Sigma, St. Louis, MO, USA). The column was washed with $20 \mathrm{mM}$ phosphate buffer $(\mathrm{pH} \mathrm{7.0)}$ and the absorbed proteins were eluted with a linear salt gradient ( 0 to $1 \mathrm{M} \mathrm{NaCl}$ ). Fractions of $6 \mathrm{~mL}$ were collected and assayed for bacteriocin activity. The active 
fractions were subjected to ultrafiltration (Amicon ultra-4, $10 \mathrm{kDa}$, Millipore, Billerica, MA, USA). The purified samples were then applied to a $C_{18} \mu$ Bondapak column (3.9 $m m \times 30 \mathrm{~cm}$, Waters, Milford, MA, USA) and subjected to HPLC (Agilent 1100 series, Agilent Technologies Inc., Palo Alto, CA, USA). The buffer used was $10 \%$ acetonitrile $0.1 \%$ trifluoroacetic acid (TFA), and flow rate was $1 \mathrm{~mL} / \mathrm{min}$. One milliliter fractions were collected, and then assayed for bacteriocin activity. Fractions were concentrated by freeze-drying for molecular mass determination. Protein concentration was determined by using the Lowry assay (Daniel et al., 1996).

\section{Molecular mass determination}

Tricine-SDS-PAGE was performed to determine the molecular mass of the putative bacteriocin (Schagger and Jagow, 1987). Protein standard and their molecular weights were as follows: triosephosphate isomerase, 26,600 Da; myoglobin, $17,000 \mathrm{Da}$; $\alpha$-lactoalbumin, $14,200 \mathrm{Da}$; aprotinin, 6,500 Da; insulin 3,496 Da; bradykinin, 1,060 Da. The part of the gel containing the sample and molecular mass markers was stained with Coomassie brilliant blue R-250. For direct detection of antimicrobial activity, second part was fixed with fixing buffer $(40 \% \mathrm{MeOH}: 10 \%$ acetic acid) for $1 \mathrm{hr}$. And then this part was washed with distilled water, overlayed with soft agar $(1 \%$, w/v) with indicator strain and incubated at $35^{\circ} \mathrm{C}$.

\section{DNA preparation and PCR detection of lacticin NK34} structural gene

L. lactis NK34 genomic DNA was isolated by lysing protoplasts (Neumann et al., 1992). The DNA primers used in this study are listed in Table 1. DNA was dissolved in 10 $\mathrm{mM}$ Tris $\mathrm{HCl}$ ( $\mathrm{pH} \mathrm{8.0)-1} \mathrm{mM} \mathrm{EDTA,} \mathrm{and} \mathrm{approximately}$ $100 \mathrm{ng}$ was subjected to amplification by the polymerase chain reaction (PCR) in a total volume of $100 \mu \mathrm{L}$ containing $2.5 \mathrm{U}$ of Taq polymerase (Solis BioDyne, Tartu, Estonia), $200 \mu \mathrm{mol} / \mathrm{L}$ dNTP (Solis BioDyne), 0.1 volume of $10 \mathrm{x}$ buffer (Solis BioDyne), $1 \mu \mathrm{mol} / \mathrm{L}$ primer(s) were set up. After up to $100 \mu \mathrm{L}$ with distilled water, $1 \mu \mathrm{L}$ genomic DNA of lactococci was added to the reaction. A DNA segment was amplified by PCR (XP cycler, Bioer, Tokyo, Japan) with synthetic DNA primers, nisin A and nis A/nis Z. DNA was amplified with nisin A primers for 40 cycles (Choi et al., 2000). Samples were denatured at $94^{\circ} \mathrm{C}$ for $5 \mathrm{~min}$ and subjected to amplification cycles in a PCR. Each cycle involved 1 min denaturation at $95^{\circ} \mathrm{C}$, followed by an annealing step at $55^{\circ} \mathrm{C}$ for $1 \mathrm{~min}$ and an extension step of $72^{\circ} \mathrm{C}$ for $1 \mathrm{~min}$. Finally, products were extended for $7 \mathrm{~min}$. The nis $\mathrm{A} / \mathrm{nis} \mathrm{Z}$ primers were denatured at $94^{\circ} \mathrm{C}$ for $5 \mathrm{~min}$ and subjected to amplification cycles in a $\mathrm{PCR}$, and consisted of denaturation at $93^{\circ} \mathrm{C}$ for $2 \mathrm{~min}$, a primer annealing step at $54^{\circ} \mathrm{C}$ for $1 \mathrm{~min}$, and an extension step at $72^{\circ} \mathrm{C}$ for $1.5 \mathrm{~min}$ (de Vos et al., 1993). Finally, products were extended for $7 \mathrm{~min}$ at the completion of 30 amplification cycles. Five microliters of the reaction mixture was analyzed on $1.2 \%(\mathrm{w} / \mathrm{v})$ agarose gels with ethidium bromide staining.

\section{Results and Discussion}

\section{Antimicrobial spectrum against bovine mastitis- related microorganisms}

L. lactis NK34 and lacticin NK34 have demonstrated antimicrobial effects against a broad range of Gram-positive bacteria including S. aureus (Lee et al., 2000; Lee et al., 2008). S. aureus, S. chromogenes, S. hominis, S. simulans, Streptococcus uberis, Enterococcus gallinarum, and Enterococcus faecium are known to cause bovine mastitis (Table 2). Among these strains, 12 strains were inhibited by lacticin NK34. Lacticin NK34, in particular, showed antimicrobial effects against two strains of S. aureus. Also, lacticin NK34 showed antimicrobial effects against a wide range of CNS strains.

\section{Sensitivity of enzyme to $\mathrm{pH}$ changes and heat treatment}

Lacticin NK34 was inactivated by protease XIV but not by protease IX, protease XIII, proteinase $\mathrm{K}, \alpha$-chymotrypsin, trypsin, and pepsin (Table 3). Activity loss due to protease XIV treatment confirmed the proteinaceous nature of lacticin NK34. Also, lacticin NK34 was stable over a pH range of 2 to 9 for $4 \mathrm{hr}$ and when heated to $30-100^{\circ} \mathrm{C}$ for $30 \mathrm{~min}$ (data not shown). Nisin's known sensitivity to $\alpha$-chymotrypsin, heat stability at low $\mathrm{pH}$ and non-toxic nature has pro-

Table 1. The primer sequence used in this study

\begin{tabular}{ccc}
\hline & & Sequence $\left(5^{\prime} \rightarrow 3^{\prime}\right)$ \\
\hline \multirow{2}{*}{ nisA/nisZ } & Forward & CGCGAGCATAATAAACGGCT \\
& Reverse & GGATAGTATCCATGTCTGAAC \\
\hline \multirow{2}{*}{ nisA } & Forward & ATGAGTACAAAGATTTTAACTTGGATTGGT \\
& Reverse & ATAAACGAATGCACTTATGATGTTACTGTT \\
\hline
\end{tabular}


Table 2. Antimicrobial spectrum of lacticin NK34 against bovine mastitis-related microorganisms

\begin{tabular}{lc}
\hline \hline \multicolumn{1}{c}{ Microorganism } & Lacticin NK34 \\
\hline Staphylococcus aureus 1573 & - \\
Staphylococcus aureus 1572 & - \\
Staphylococcus aureus 1512 & - \\
Staphylococcus aureus 1504 & - \\
Staphylococcus aureus 7 & + \\
Staphylococcus aureus 8 & + \\
Staphylococcus chromogenes 10 & + \\
Staphylococcus chromogenes 19 & + \\
Staphylococcus hominis 9 & + \\
Staphylococcus simulans 78 & + \\
Streptococcus uberis E290 & + \\
Enterococcus gallinarum E362 & + \\
Enterococcus faecium E363 & + \\
Enterococcus avium E369 & + \\
Enterococcus faecium E374 & - \\
Streptococcus agalactiae ATCC 13813 & + \\
Pseudonocardia autotrophica KCTC 9455 & + \\
\hline
\end{tabular}

+ , positive; -, negative.

Table 3. Enzyme sensitivity of lacticin NK34

\begin{tabular}{lc}
\hline \hline \multicolumn{1}{c}{ Enzyme } & Residual activity $(\mathrm{AU} / \mathrm{mL})$ \\
\hline Control & 12,800 \\
Protease IX & 12,800 \\
Protease XIII & 12,800 \\
Protease XIV & 1,600 \\
Proteinase K & 12,800 \\
$\alpha$-Chymotrypsin & 12,800 \\
Trypsin & 12,800 \\
Pepsin & 12,800 \\
\hline
\end{tabular}

moted its widespread use (Choi et al., 2000). These experiments show that lacticin NK34 possesses useful properties that may contribute to a potential commercial application in treating bovine mastitis.

Mode of inhibition of lacticin NK34 against Staphylococcus simulans 78

The addition of lacticin NK34 to S. simulans 78 caused a loss in their viability when compared to control cultures

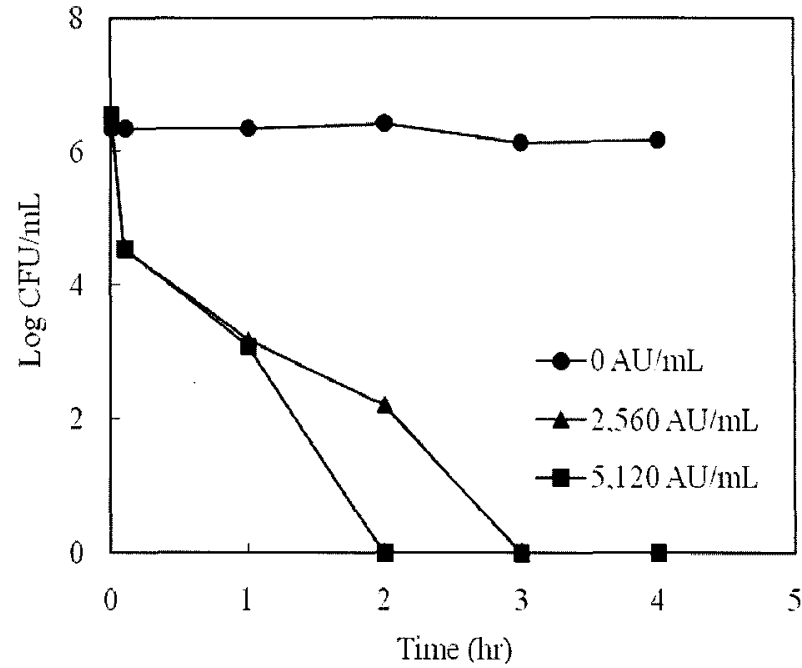

Fig. 1. Mode of inhibition of lacticin NK34 against $S$. simulans 78.

(Fig. 1). After $3 \mathrm{hr}$, the addition of 2,560 AU/mL of lacticin NK34 killed $S$. simulans 78 below $1 \log C F U / m L$. And the addition of 5,120 AU/mL of lacticin NK34 killed below 1 $\log \mathrm{CFU} / \mathrm{mL}$ after $2 \mathrm{hr}$. These data indicate that lacticin NK34 showed a bactericidal mode of inhibition against $S$. simulans 78. Bactericidal mode of action is characteristics of the bacteriocin of LAB (Davey et al., 1981).

\section{Purification of lacticin NK34}

The purification of lacticin NK34 was achieved by the four steps $(60 \%$ ammonium sulfate precipitation and anionexchange chromatography (AEC), ultrafiltration, and HPLC) (Table 4). Bacteriocin has generally hydrophobic and cationic antimicrobial compounds (Kaenhammer 1998; O'Sullivan et al., 2002). But, lacticin NK34 has the higher yield in AEC. In this step, compound with bacteriocin activity were eluted between $0.15-0.33 \mathrm{M}$ of $\mathrm{NaCl}$. In the second step, collected active fractions from AEC were subjected to ultrafiltraiton. The recovery of bacteriocin activity was $70 \%$ after the ultrafiltration step. The final step of purification was used RP-HPLC, where one peak was eluted at retention time of $4.2 \mathrm{~min}$ (Fig. 2). This peak was active against $S$. simulans 78. Analysis of the activity fraction isolated after AEC by tricin-SDS-PAGE, and direct detection of antimicrobial

Table 4. Purification of lacticin NK34

\begin{tabular}{lccrc}
\hline \hline \multicolumn{1}{c}{ Purification step } & $\begin{array}{c}\text { Total protein } \\
(\mathrm{mg})\end{array}$ & Total activity (AU) & $\begin{array}{c}\text { Specific activity } \\
\text { (AU/mg) }\end{array}$ & $\begin{array}{c}\text { Recovery } \\
(\%)\end{array}$ \\
\hline Culture supernatant & 2,520 & 144,000 & 57.14 & 100 \\
Ammonium sulfate precipitation & 348 & 307,200 & 882.76 & 213 \\
Anion-exchange chromatography & 36 & 100,800 & 2,800 & 70 \\
Ultrafiltration & 28.8 & 100,800 & 3,500 & 70 \\
HPLC & 11.35 & 64,000 & 5,639 & 44 \\
\hline
\end{tabular}




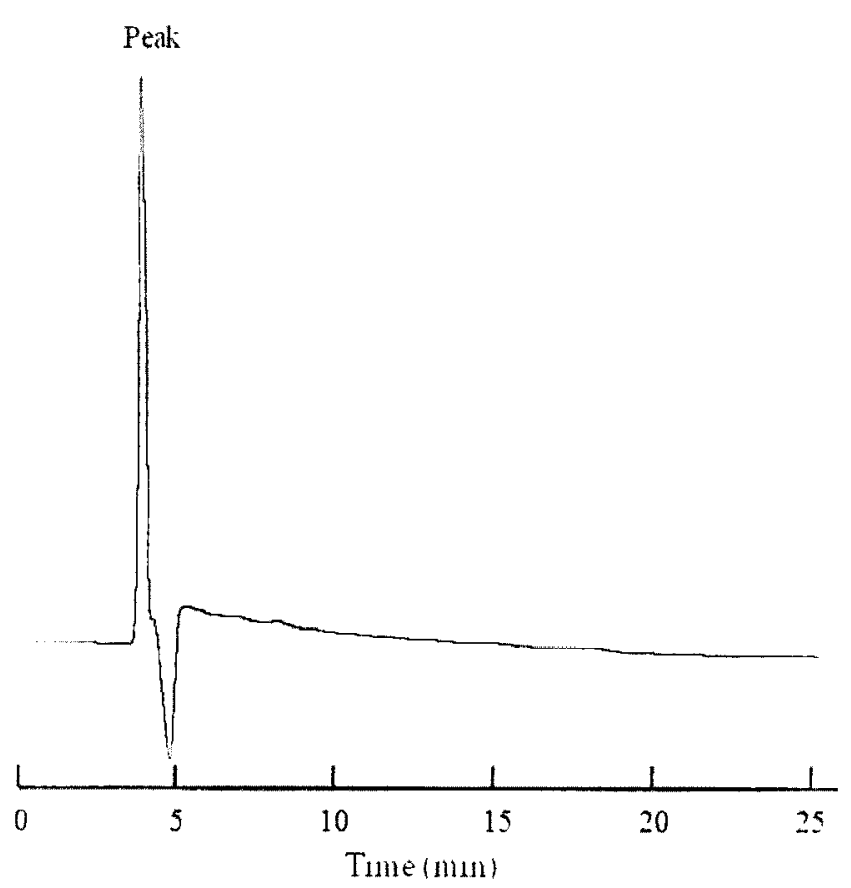

Fig. 2, Reverse-phase HPLC chromatogram of ultrafiltered bacteriocin monitored by absorbance at $220 \mathrm{~nm}$. The peak with $4.2 \mathrm{~min}$ retention time exhibited bacteriocin activity.

(a)

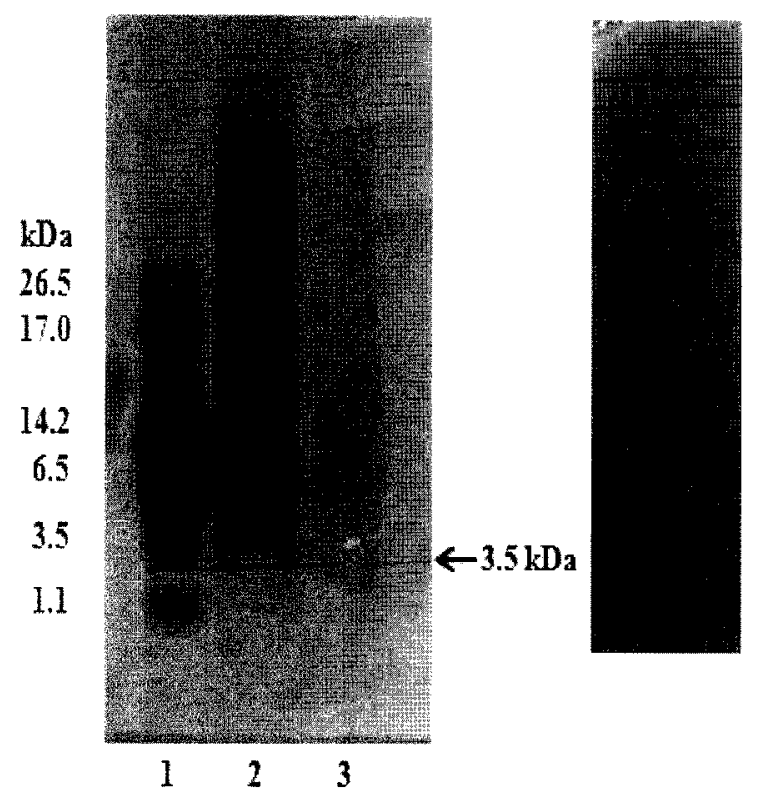

Fig. 3. Tricin-SDS-PAGE of the purified lacticin NK34. Lane 1 , size marker $(26.5,17.0,14.2,6.5,3.5,1.1 \mathrm{kDa})$; Lane 2,3 , fraction from anion-exchange chromatography; (b) the gel overlaid with $S$. simulans 78 .

activity on the electrophoresis gel indicated that molecular mass of the bacteriocin is approximately $3.5 \mathrm{kDa}$. The overlaid part of the gel shows that this fraction was shown antimicrobial effect against $S$. simulans 78 as about $3.5 \mathrm{kDa}$ (Fig. 3). However, analysis of the activity fraction from HPLC by tricin-SDS-PAGE was not shown as band.

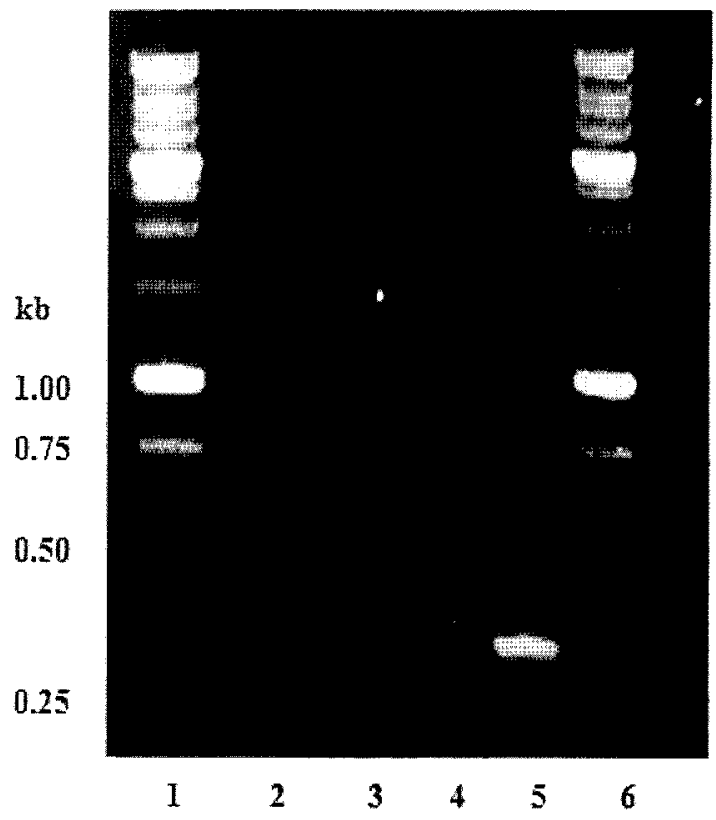

Fig. 4. Agarose gel electrophoresis of PCR products with nisin $\mathbf{A}$ and nisin $\mathbf{Z}$ primers. Lane 1, 5, DNA leading marker; Lane 2, 3, nisA specific primer and genomic DNA of $L$. lactis NK34; Lane 4, 5, nisA/nisZ specific primer and genomic DNA of L. lactis NK34.

Genetic determination by PCR of the presence of nisin $A$ and nisin $Z$ structural genes

Using the published sequence of the nisin structural gene (Dodd et al., 1992), two primers, which are complementary to sequences occurring proximal to the 3' and 5' ends of the nisin $\mathrm{A}$ and nisin $\mathrm{Z}$ structural gene (nisA), were synthesized. Using the nisA genomic DNA of L. lactis NK34, no PCR products were obtained with the nisA-specific primer and this new reverse primer (Fig. 4, lane 2 and 3). But nisA/nisZ primers did amplify a product of $300 \mathrm{bp}$ from template DNA (Fig. 4, lane 4 and 5). Therefore, bacteriocin produced by $L$. lactis NK34 was found to be a nisin-like bacteriocin. Nisin $A$ and nisin $Z$ primers generated 300 bp fragments. This result indicates that $L$. lactis NK34 contain the nisin $Z$ gene.

In conclusion, bovine mastitis pathogens such as several methicillin resistant Staphylococcus aureus and coagulase negative Staphylococcus were inhibited by lacticin NK34. The molecular mass of lacticin NK34 was about $3.5 \mathrm{kDa}$, as determined by tricin-SDS-PAGE. These results indicate that lacticin NK34 is a nisin-like bacteriocin, and could be used as an antimicrobial alternative for livestock.

\section{Acknowledgements}

This study was funded by a research grant from National Veterinary Research \& Quarantine Service and the Brain Korea 21 Project, Korea. 


\section{References}

1. Bradley, A. J. (2002) Bovine mastitis: an evolving disease. Vet. J. 164, 116-128.

2. Choi, H. J., Cheigh, C. I., Kim, S. B., and Pyun, Y. R. (2000) Production of a nisin-like by Lactococcus lactis subsp. lactis A164 isolated from Kimchi. J. Appl. Microbiol. 88, 563-571.

3. Coelho, M. L. V., Nascimento, J. S., Fagundes, P. C., Madureira, D. J., Oliveira, S. S., Briot, M. A. V. P., and Bastos, M. C. F. (2007) Activity of staphylococcal bacteriocins against Staphylococcus aureus and Streptococcus agalactiae involved in bovine mastitis. Res. Microbiol. 158, 625-630.

4. Daniel, M. B., Michael, D. T., and Stuart, J. E. (1996) Protein methods. $2^{\text {nd }}$ ed, Wiley-Liss, Inc., New York, NY, pp. 68-71.

5. Davey, G. P., Richardson, P. N., and Nebo, B. T. (1981) Purification and some properties of diplococcin from Streptococcus cremoris 346. Appl, Environ. Microbiol. 41, 84-89.

6. Delves-Broughton, J. (1990) Nisin and its uses as a food preservative. Food Technol. 44, 100-117.

7. De Vos, W. M., Mulders, J. W. M., Siezen, R. J., Hugenholtz, J., and Kuipers, O. P. (1993) Properties of nisin Z and distribution of its gene, nisZ, in Lactococcus lactis. Appl. Environ. Microbiol. 59, 213-218.

8. Dodd, H. M., Horn, N., Hao, Z., and Gasson, M. J. (1992) A lactococcal expression system for engineered nisins. Appl. Environ. Microbiol. 58, 3683-3693.

9. Green, M. J., Green, L. E., Medley, G. F., Schukken, Y. H., and Bradley, A. J. (2002) Influence of dry period bacterial intramammary infection on clinical mastitis in dairy cows. $J$. Dairy Sci. 85, 2589-2599.

10. Kim, H. J., Kim, J. H., Son, J. H., Seo, H. J., Park, S. J., Paek, N. S., and Kim, S. K. (2004) Characterization of bacteriocin produced by Lactobacillus bulgaricus. J. Microbiol. Biotechnol. 14, 503-508.

11. Kim, H. J., Lee, N. K., Lee, D. S., Hong, W. S., Lee, S. R., Kim, C. J., and Paik, H.-D. (2008) Improvement of microbiological safety of sous vide processed soybean sprouts: nisin and Bacillus cereus challenge. Food Sci. Biotechnol. 17, 166-171.

12. Klaenhammer, T. R. (1998) Bacteriocins of lactic acid bacteria. Biochimie 70, 337-349.

13. Lee, N. K., Choi, I. A., Park, Y. H., Kim, J. M., Kim, J. M., Jung, S. C., and Paik, H.-D. (2008) Screening of antimicrobial lactic acid bacteria against bovine mastitis. Korean $J$. Food Sci. 27, 543-547.

14. Lee, N. K., Jun, S. A., Ha, J. U., and Paik, H.-D. (2000)
Screening and characterization of bacteriocinogenic lactic acid bacteria from jeot-gal, a Korean fermented fish food. $J$. Microbiol. Biotechnol. 10, 423-428.

15. Lee, N. K., Lee, J. Y., Kwak, H. G., and Paik, H.-D. (2008) Perspectives for the industrial use of bacteriocin in dairy and meat industry. Korean J. Food Sci. Ani. Resour. 28, 1-8.

16. Lee, N. K., and Paik, H.-D. (2001) Partial characterization of lacticin NK24, a newly identified bacteriocin of Lactococcus lactis NK24 isolated from jeot-gal. Food Microbiol. 18, 1724.

17. Nes, I. F., Yoon, S. S., Diep, D. B. (2007) Ribosomally synthesized antimicrobial peptides (bacteriocins) in lactic acid bacteria: a review. Food Sci. Biotechnol. 16, 675-690.

18. Nascimento, S. J., Santos, K. R. N., Gentilini, E., Sordelli, D., and Bastos, M. C. F. (2002) Phenotypic and genetic characterization of bacteriocin-producing strains of Staphylococcus aureus involved in bovine mastitis. Vet. Microbiol. 85 , 133-144.

19. Neumann, B., Pospiech, A., and Schairer, H. U. (1992) Rapid isolation of genomic DNA from Gram-negative bacteria. Trends Genet. 8, 332-333.

20. Oh, S., Heo, H. J., Park, D. J., Kim, S. H., Lee, S. J., and Imm, J. Y. (2006) Effect of encapsulated bacteriocin on acid production and growth of starter cultures in yoghurt. Food Sci. Biotechnol. 15, 902-907.

21. O'Sullivan, L., Ross, R. P., and Hill, C. (2002) Potential of bacteriocin-producing lactic acid bacteria improvements in food safety and quality. Biochimie 84, 593-604

22. Ryan, M. P., Meaney, W. J., Ross, R. P., and Hill, C. (1998) Evaluation of lacticin 3147 and a teat seal containing this bacteriocins for inhibition of mastitis pathogens. Appl. Environ. Microbiol. 64, 2287-2290.

23. Schagger, H., and von Jagow, G. (1987) Tricine-sodium dodecyl sulfate-polyacrylamide gel electrophoresis for the separation of proteins in the range from 1 to $100 \mathrm{kDa}$. Anal. Biochem. 166, 368-379.

24. Twomey, D. P., Wheelock, A. I., Flynn, J., Meaney, W. J., Hill, C., and Ross, R. P. (2000) Protection against Staphylococcus aureus mastitis in dairy cows using a bismuth-based teat seal containing the bacteriocin, lacticin 3147, J. Dairy Sci. 83, 1981-1988.

25. Weinbrenner, D. R., Barefoot, S. F., and Grinstead, D. A. (1997) Inhibition of yoghurt starter cultures by jenseniin G, a Propionibacterium bacteriocin. J. Dairy Sci. 80, 1246-1253.

(2008. 9. 1 접수/2008. 9. 21 수정/2008. 9. 21 채택) 